\title{
REVITALISASI PEMBELAJARAN PENDIDIKAN AGAMA HINDU DI ERA DISRUPSI DIGITAL
}

\author{
Ni luh Ari Kusumawati \\ Universitas Hindu Negeri I Gusti Bagus Sugriwa Denpasar \\ email : niluharikusumawati@gmail.com
}

Diterima: 25 Maret 2021, Direvisi : 22 April 2021, Diterbitkan : 27 April 2021

\begin{abstract}
In the era of digital disruption, the development of science and technology is very rapidly increasingly encouraging reforms in various fields, especially in the field of education in utilizing the results of technology itself in the learning process. Religious education is a compulsory subject that is applied at every level of education. One of them is the learning subject of Hindu religious education. Revitalization of Hindu religious education learning in the era of digital disruption must continue to be encouraged so that superior Hiindu human resources are realized. Educators are currently required to be able to master various technologies so that they are able to use the various learning facilities provided in schools. Educators are required to develop skills by making interactive learning media by utilizing available educational technology. Effective learning requires good planning before the learning process is carried out. Every educator is required to be able to create interactive learning media. Currently, teachers are also required to have various soft skills that can be used to support the learning process. The complex problems in learning Hindu religious education include the system of learners, educators and students. So that innovation and progress in learning Hindu religious education can be realized. Revitalization of Hindu religious education learning is expected to be able to face the challenges of Hindus in the realm of education easily. So that various elements ranging from the younger generation to the elderly can work together to build a better Hindu religious education and create superior Hindu human resources $(H R)$ so that the goals of national education can be achieved.
\end{abstract}

Keywords : Revitalization, Hindu Religion Learning, Digital Disruption

\section{PENDAHULUAN}

Pendidikan nasional dapat menjadi fundamental bagi arah perkembangan sistem pembelajaran pendidikan agama Hindu dalam rangka meningkatkan Sumber Daya Manusia Hindu yang unggul. Pendidikan merupakan sesuatu yang sangat penting bagi kehidupan setiap orang, untuk tetap dapat menunjukkan eksistensi dan meningkatkan taraf hidup seseorang menjadi lebih baik. Perkembangan teknologi yang sangat pesat di dunia pendidikan membawa pengaruh yang sangat signifikan terhadap proses pembelajaran peserta didik. Teknologi yang dapat dimanfaatkan dengan baik maka akan membantu tercapainya proses pembelajaran yang efektif. Pembelajaran pendidikan agama Hindu yang berlangsung saat ini cenderung menimbulkan kepasifan peserta didik sehingga proses pembelajaran hanya berlangsung satu arah. Kurangnya soft skill di bidang teknologi pendidikan yang dimiliki oleh seorang pendidik agama Hindu menyebabkan pembelajaran hanya sebatas transfer ilmu dari pendidik kepada 
peserta didik. Pendidikan agama Hindu yang dibutuhkan saat ini adalah pendidikan yang tidak hanya transfer ilmu semata (kognitif), tetapi adalah pendidikan yang dapat mengembangkan sikap (afektif) dan keterampilan (psikomotorik) peserta didik. Pemanfaataan berbagai teknologi digital pada proses pembelajaran pendidikan agama Hindu harus dilakukan, karena peserta didik yang dihadapi pada era ini adalah peserta didik yang melek teknologi sehingga seluruh pendidik juga harus melek teknologi. Materi pembelajaran pendidikan agama Hindu harus bersifat kontektual yang berkaitan dengan kehidupan sehari-hari peserta didik bukan hanya sekedar teori. Tantangan pendidikan agama Hindu di setiap era tentu berbeda-beda, dimana sekarang memasuki era disrupsi digital. Sehingga revitalisasi pembelajaran pendidikan agama Hindu di era disrupsi saat ini sangat diperlukan.

Di era disrupsi digital ini terjadi pergeseran aktivitas manusia yang semula lebih banyak beraktivitas secara fisik kemudian beralih dengan memanfaatkan teknologi digital. Era disrupsi digital menunjukan perkembangan teknologi yang sangat maju yang berujung pada pergeseran budaya dan lingkungan yang kemudian mempengaruhi pola pikir generasi now. Tantangan pendidikan agama Hindu di era disrupsi digital ini salah satunya adalah kurikulum yang disajikan dengan begitu padat dan semakin banyaknya guru yang berusia di atas 50 tahun atau dalam usia yang akan segera pensiun. Sementara hal yang diperlukan untuk dapat meningkatkan hasil pembelajaran pendidikan agama Hindu adalah seorang guru yang memiliki segudang inovasi. Karena peserta didik saat ini merupakan generasi yang harus akan teknologi. Apabila pradigma inovasi dalam pembelajaran pendidikan agama Hindu terbentuk pada pendidik maka pembelajaran agama Hindu akan semakin berkualitas.

Pendidikan agama Hindu merupakan pembelajaran yang sangat penting pada setiap jenjang pendidikan. Pembentukan nilai-nilai moral keagamaan yang dilakukan sangat mempengaruhi karakter peserta didik pada usia mendatang. Melalui pendidikan agama Hindu dilakukan penanaman nilai, norma dan pembentukan karakter yang dapat dilakukan kepada seluruh umat Hindu khususnya untuk peserta didik Hindu. Karena peserta didik merupakan gerenasi penerus bangsa (Suwantana 2018). Praktik pendidikan formal dan non formal dalam proses pembelajaran yang dilakukan di pasmaran maupun di sekolah masih dirasa sangat kurang. Sehingga hal tersebut berdampak pada penyerapan ilmu pengetahuan dan wawasan yang tidak seberapa dalam, selama proses pembelajaran berlangsung. Kemajuan ilmu pengetahuan dan teknologi membawa pengaruh yang sangat besar terhadap penggunaan alatalat bantu mengajar yang digunakan disekolah-sekolah (Sanaky 2013). Dalam proses pembelajaran kebanyakan peserta didik hanya mengejar nilai saja tanpa begitu memperhatikan dan memahami substansinya. Ditambah dengan minat literasi yang sangat rendah saat ini, menyebabkan tidak berkembangnya pola pikir peserta didik dan peserta didik masih sangat tergantung dengan berbagai buku offline. Padahal seiring dengan berkembangnya ilmu pengetahuan dan teknologi banyak sekali disediakan e-book, e-learning, platform belajar online dan lain sebagainya. Meningkatkan kemampuan dan keterampilan sumberdaya Hindu melalui pendidikan agama Hindu dengan melahirkan operator dan analis handal di bidang manajemen pendidikan sebagai pendorong kemajuan pendidikan berbasis teknologi informasi di Indonesia menjawab tantangan Industri 4.0. Pembelajaran harus dapat berkolaborasi dengan memanfaatkan berbagai teknologi yang ada (Syamsuar dan Reflianto 2018). Dan juga lembaga pendidikan formal berbasis agama Hindu masih sangat minim sekali di Bali dan juga di luar daerah Bali. Hal tersebut menjadi poin yang sangat penting untuk diperhatikan, sehingga Sumber Daya Manusia (SDM) Hindu yang unggul dapat terwujud. Minimnya tenaga pendidik di sekolah umum bagi peserta didik yang beragama Hindu, mengakibatkan tak jarang peserta didik hanya mendapatkan informasi seputaran pelajaran agama Hindu dari pasraman. Hal ini banyak terjadi pada sekolah-sekolah umum yang berada di luar Bali terutama daerah terpencil atau $3 \mathrm{~T}$. 
Revitalisasi pembelajaran pendidikan agama Hindu di era disrupsi digital harus terus digalakkan. Transformasi pendidikan agama Hindu sebagai upaya menciptakan sumber daya manusia yang unggul dengan berbagai kompleksitas kehidupan. Dalam melakukan inovasi pembelajaran pendidikan agama Hindu diperlukan seorang pendidik dari lulusan multi-skill yaitu The Outside in yang berarti apa yang menjadi kebutuhan masyarakat (dunia usaha) menjadi titik tolak memperbarui sistem dalam pendidikan kita (Pramudianto, 2020). Pergeseran budaya dan perilaku yang terjadi pada generasi saat ini dengan generasi sebelumnya menimbulkan gap antar generasi yang sangat lebar. Sehingga menuntut pendidik untuk memiliki skill dan inovasi yang berbeda dalam mendidik setiap generasi. Dalam mendidik generasi now erat kaitannya dengan budaya, teknologi dan inovasi. Pergeseran pradigma yang dulu memandang sumber daya manusia sebagai asset yang berharga kini telah bergeser sebagai intangible asset (human idea) yang sangat berperan strategis dalam kelanjutan hidup.

Oleh karena itu pembelajaran di era disrupsi digital juga harus mengembangkan kecapakan pendidikan abad 21 untuk saling berkolaborasi. Di era disrupsi digital saat ini pemanfaatan platform digital melalui akun-akun media sosial seperti youtube, instagram, twitter, facebook dan lain sebagainya berkembang sangat pesat. Termasuk pembuatan aplikasi digital yang dapat diunduh oleh para pendidik dan pelajar. Dalam proses pembelajaran, media pembelajaran sangat berperan penting untuk mendukung proses pembelajaran. Setiap pendidik dituntut untuk bisa menciptakan media pembelajaran interaktif. Salain faktor pendidikan yang terdapat pada lingkungan sekolah, pendidikan di lingkungan keluarga merupakan faktor utama yang mempengaruhi perkembangan seorang anak. Sehingga dapat disimpulkan bahwa untuk dapat membentuk peserta didik yang unggul dalam prestasi maka diperlukan kerjasama antara orang tua dan peserta didik. Menciptakan budaya coaching baik di lingkungan sekolah maupun keluarga sangat mempengaruhi perkembangan potensi yang dimiliki oleh peserta didik.

\section{METODE}

Metode penelitian yang digunakan dalam penelitian ini adalah kualitatif deskriptif dimana peneliti ingin memaparkan dan menggambarkan revitalisasi pembelajaran pendidikan agama Hindu di era disrupsi digital. Penelitian kualitatif deskriptif berusaha untuk mendeskripsikan seluruh gejala atau keadaan dengan apa adanya pada saat penelitian dilakukan. Teknik pengumpulan data dalam penelitian ini adalah studi kepustakaan (library research), simak dan catat. Instrumen umumnya adalah peneliti sendiri dimana peneliti akan membaca buku atau jurnal, mencermati dan mencatat tujuan dari penelitian.

\section{HASIL DAN PEMBAHASAN}

\subsection{Pengembangan Media Pembelajaran Interaktif berbasis digital dalam meningkatkan Kualitas Pembelajaran Pendidikan Agama Hindu}

Media pembelajaran interaktif merupakan media pembelajaran dengan menggunakan atau memanfaatkan media teknologi yang mutakhir. Seiring dengan kemajuan teknologi multimedia khususnya pada bidang komunikasi, memaksa kita untuk mengikuti perkembangan teknologi (Ilham, 2014). Media pembelajaran interaktif merupakan suatu sistem pengajaran yang digunakan oleh pendidik untuk mendukung proses pembelajaran dan memudahkan pendidik untuk menyampaikan materi pembelajaran kepada peserta didik baik melalui video, power point dan lain sebagainya. Media pembelajaran interaktif sebagai alat bantu berbasis multimedia yang digunakan untuk mempermudah menyampaikan materi pembelajaran dari pendidik kepada peserta didik sehingga terjadi komunikasi aktif secara dua arah antara multimedia dengan peserta didik dengan tujuan untuk mempermudah proses pembelajaran. Peran multimedia interaktif semakin memegang peranan yang sangat penting dalam bidang pendidikan sejalan dengan pertumbuhan pengguna komputer dan pertumbuhan internet di 
masyarakat yang semakin memudahkan aliran produk multimedia dari satu komputer ke komputer lainnya (Nandi 2016).

Pengembangan media pembelajaran interaktif dalam pembelajaran pendidikan agama Hindu sangat diperlukan karena media pembelajaran sangat menentukan hasil dan kualitas dalam pembelajaran. Media pembelajaran interaktif sebagai alat bantu pendidik yang sangat mutakhir dalam menyampaikan materi pembelajaran kepada peserta didik. Proses pendidikan masa kini seringkali dikaitkan dengan unsur penerapan nilai-nilai murni dan pembentukan jati diri peserta didik (Zakhi, 2012). Pendidik dituntut untuk dapat menciptakan media pembelajaran yang aplikatif yang dapat menunjang proses pembelajaran dengan memanfaatkan berbagai teknologi pendidikan. Dengan pengembangan media pembelajaran interaktif diharapkan pendidik lebih mudah menyampaikan materi pembelajaran pendidikan agama Hindu kepada peserta didik sehingga tujuan dari pembelajaran pendidikan agama Hindu itu sendiri dapat terwujud dengan baik.

Untuk dapat mewujudkan kualitas Sumber Daya Manusia (SDM) Hindu yang unggul maka pendidikan memegang peranan yang sangat penting. Tingkat pendidikan seseorang mempengaruhi taraf hidupnya. Di dalam masyarakat sangat terlihat perbedaan antara orang yang bependidikan dengan orang yang tidak berpendidikan. Sehingga di dalam masyarakat terjadi stratifikasi pendidikan yaitu penggolongan seseorang berdasarkan jenjang pendidikan. Untuk dapat meningkatkan kualitas SDM Hindu yang unggul salah satu kuncinya adalah terletak pada pembelajaran pendidikan agama Hindu yang diterapkan di berbagai sekolah. Pembelajaran agama Hindu diharapkan mampu menghasilkan generasi Hindu yang unggul dan memiliki karakter yang baik sehingga dapat menjadi pemimpin dimasa depan. Dalam pembelajaran pendidikan agama Hindu metode, model dan media pembelajaran merupakan hal yang sangat penting mempengaruhi hasil dan kualitas pembelajaran. Media pembelajaran merupakan alat bantu yang digunakan oleh pendidik untuk membantu proses penyampaian informasi dalam pembelajaran kepada peserta didik sehingga pembelajaran yang efektif dan efisien dapat terwujud. Tetapi pada nyata bahwa banyak pendidik yang belum memiliki kualitas SDM yang memadai. Dengan perkembangan teknologi yang begitu pesat pendidik dituntut untuk memanfaatkan teknologi pendidikan dalam pembelajaran. Pengembangan media pembelajaran sangat dibutuhkan untuk dapat meningkatkan kualitas pembelajaran. Pengembangan media pembelajaran interaktif dalam pembelajaran sangat diperlukan untuk dapat mendukung proses pembelajaran (Arikunto 2019). Dengan memanfaatkan teknologi pendidikan yang ada diharapkan pembelajaran pendidikan agama Hindu menjadi lebih bervariasi dan juga dapat menyenangkan peserta didik.

Di era distupsi digital pendidik dituntut untuk menggunakan media pembelajaran interaktif berbasis teknologi digital. Pengembangan media pembelajaran interaktif dalam pembelajaran pendidikan agama Hindu dapat dilakukan dengan menggunakan berbagai media sebagai berikut :

a. Media pembelajaran interaktif berbasis e-Learning meliputi moodle, google classroom, moodle,schoology, edmodo, fedena, edLink, ilmukomputer.com, pesonaedu dan lain sebagainya.

b. Media pembelajaran interaktif berbasis software meliputi microsoft power point, pootown, pothoshop, adobe premiere, rekentest, software kalkulator ilmiah Sicyon lite, animals for kids 2.1, Chinese toolbox free 9.1.2, chemdigit, portable balabolkaa 1.32.0.463, tinypiano vo.8e, KBBI, kamus inggris indonesia, kamus jawa indonesia, software mengetik 10 jari dan lain sebagainya.

c. Media pembelajaran interaktif berbasis aplikasi android meliputi RuangGuru, KelasKita, Quipper, Quizziz,Kkahoot, aplikasi belajar online tryout UN SD, CBT UN SMP, star chart dan lain sebagainya. 
Software pembuat media pembelajaran interaktif yang paling banyak digunakan dan harus diketahui oleh pendidik adalah prezi, flypaper, Camtasia, snagit, lectora, adobe flash professional, windows movie maker, micrososft power point, filmora wondershare, GoAnime, photoshop, coreldraw dan lain sebagainya. Selain software media pembelajaran interaktif yang dapat digunakan oleh pendidik dalam pembelajaran pendidikan agama Hindu adalah juga dapat dengan memanfaatkan platform digital untuk membuat media pembelajaran yang dapat mendukung proses pembelajaran khususnya melalui youtube dan tiktok yang di era distrupsi digital ini banyak di akses oleh peserta didik. Dengan pengembangan media pembelajaran interaktif dalam pembelajaran pendidikan agama Hindu diharapkan tatangan umat Hindu dalam ranah pendidikan dapat teratasi dan dapat dihadapi dengan mudah. Sehingga berbagai elemen mulai dari generasi muda hingga orang tua dapat bersinergi untuk membangun pendidikan agama Hindu yang lebih baik sehingga tujuan pendidikan nasional dapat tercapai.

\subsection{Pengembangan Soft Skill Guru dalam pembelajaran Pendidikan Agama Hindu di era disrupsi digital}

Perubahan yang terjadi di berbagai bidang kehidupan menyebabkan terbentuknya lingkungan dan perilaku baru. Disrupsi digital revolusi industri 4.0 sebagai pemicu berkembangnya berbagai teknologi pendidikan yang sangat mempengaruhi proses pembelajaran. Peserta didik saat ini berada pada fase transisi yang diakibatkan oleh pandemi covid-19, sehingga memerlukan perhatian yang lebih dalam menyikapi perubahan yang ada. Berbagai tantangan yang dihadapi oleh peserta didik dalam situasi yang dilematis dalam menentukan pilihan yang terbaik bagi dirinya. Peran guru sangat penting dalam membentuk kesuksesan peserta didik (Anshori 2016). Bila sekolah tidak mampu menciptakan kesuksesan dalam diri peserta didik pada setiap harinya, maka peserta didik akan cenderung mencari lingkungan yang lainnya. Adapun soft skill yang harus dimiliki oleh serorang guru dalam pembelajaran pendidikan agama Hindu di era disrupsi digital adalah sebagai berikut:

\section{a. Inovasi}

Dalam menghadapi berbagai tantangan di dunia pendidikan seorang guru harus dapat melakukan inovasi dalam pembelajaran. Inovasi berasal dari bahasa latin innovates atau innovare yang berarti memperbarui atau mengubah. Inovasi merupakan proses penerapan atau penciptaan suatu hal yang memiliki nilai bagi orang lain dan dapat diukur. Inovasi dalam pembalajaran merupakan penciptaan produk, jasa atau idea yang dapat diterapkan dalam mendukung proses pembelajaran. Inovasi dalam pembelajaran pendidikan agama Hindu, seorang pendidik harus mampu menciptakan suasana pembelajaran yang menyenangkan sehingga memicu munculnya ide-ide kreatif. Dalam pembelajaran di kelas yang terpenting adalah kualitas pembelajarannya bukan seberapa lama pembelajaran itu dilakukan. Pendidik harus open minded (memiliki pemikiran yang luas) dan memiliki pemikiran out of the box untuk dapat mengkombinasikan ide-ide secara nyata yang selanjutnya akan menjadi sebuah temuan baru yang dapat digunakan untuk membantu proses pembelajaran agar dapat berjalan secara efektif.

\section{b. Kemampuan menggunakan teknologi digital}

Di era disrupsi digital ini seorang pendidik dituntut utuk dapat menguasai teknologi pendidikan yang ada karena proses pembelajaran tidak dapat dilepaskan dari peran teknologi. Perkembangan teknologi digital saat ini memicu pendidik harus terus mengikuti perkembangan zaman dan teknologi yang ada. Pendidik harus mampu mengusai berbagai media pembelajaran berbasis teknologi seperti google classroom, power point, video pembelajaran, google meet, zoom dan lain sebagainya. Sehingga proses pembelajaran dapat mengikuti era digital saat ini dan berjalan secara efisien. Pendidik juga harus dapat mengakses berbagai materi pembelajaran yang telah tersedia secara online yang kemudiaan dimanfaatkan dalam proses pembelajaran. Penguasaan teknologi dalam proses pembelajaran dapat menciptakan pembejaran yang bukan 
hanya sekedar abstraksi semata melainkan juga pembelajaran yang berisfat praktis dan kontektual.

\section{c. Collaboration dan Analytical Thingking}

Seorang pendidik harus mempunyai kemampuan untuk dapat berkolaborasi yang meliputi kemampuan menyatukan potensi yang dimiliki dengan potensi orang lain untuk mencapai pembelajaran yang efektif. Kolaborasi timbul atas dasar pemikiran bahwa seseorang tidak akan mungkin hidup tanpa bersinergi dengan orang lain. Collaborative learning sebagai situasi dimana terdapat dua atau lebih orang belajar secara bersama-sama dengan memanfaatkan sumber daya dan keterampilan satu sama lainnya. Pembelajaran kolaboratif menekankan pada pengembangan potensi yang dimiliki oleh peserta didik untuk mencapai tujuan pembelajaran. Peserta didik meyakini setiap potensi yang dimilikinya dan kemudian dimonitoring oleh pendidik (guru). Pendidik dan peserta didik harus berkolaborasi dimana pendidik membimbing dan kemudian peserta didik menemukan informasi dan menjawab setiap pertanyaan yang diberikan. Kemampuan dalam aspek kognitif dan psikomotorik yang dimiliki oleh peserta didik tentu berbeda-beda. Oleh karena itu pendidik harus menghargai setiap perbedaan tersebut untuk kemudian saling bekerja sama mencapai suatu tujuan.

Peserta didik di era disrupsi digital mempunyai daya pikir yang kritis sebagai bagian dari hidupnya. Sehingga yang diperlukan oleh pendidik dalam mendidik peserta didik adalah analytical thingking sebagai suatu pemecahan berbagai kompleksitas permasalahan di dunia pendidikan. Aturan dasar dalam berpikir kritis adalah memaksa pikiran kita untuk menyebar dengan memikirkan banyak alternatif, kemudian membuat lebih sempit dengan memilih alternatif terbaik saat ini dengan segara mitigasi resiko (Pramudianto 2020). Seorang pendidik yang memiliki kempuan analytical thingking dengan mudah dapat mengidentifikasi permasalahan, menemukan solusi permasalahan (problem solving) dan kemampuan dalam membuat sebuah keputusan (decision making). Perilaku berpikir kritis yang harus dimiliki oleh seorang pendidik meliputi berpikir kreatif dan kritis, memberi solusi dan kemudian menemukan suatu pengetahuan baru yang dapat digunakan untuk membantu proses pembelajaran.

\section{d. Multi Tasking/ Paralel Tasking}

Pendidik memegang peran penting dalam mencerdasakan kehidupan bangsa. Multi tasking merupakan kemampuan untuk mengerjakan sesuatu dalam waktu yang bersamaan (Pramudianto 2020). Untuk dapat menjadi pendidik yang memiliki kemampuan multi tasking di era disrupi digital saat ini tidak mudah. Pendidik selain memiliki kemampuan mengajar dan mendidik juga harus memiliki kemapuan multi tasking. Contohnya pada pembelajaran di kelas, pendidik pada saat menjelaskan materi pembelajaran di kelas juga harus memperhatikan perilaku peserta didik pada saat mengikuti pembelajaran tersebut. Hal ini merupakan salah satu contoh multi tasking pada tingkat sederhana yang harus dimiliki oleh seorang pendidik. Multi tasking di era disrupsi digital ini lebih menuntut kepada seorang pendidik untuk menguasai berbagai teknologi digital dan kemudian mengkolaborasikannya dalam proses pembelajaran.

\subsection{Revitaslisasi Pembelajaran Pendidikan Agama Hindu di Era Disrupsi Digital}

Perkembangan pembelajaran pendidik agama Hindu di awali pada zaman upanisad, dimana seorang murid duduk di dekat kaki seorang guru untuk mendengarkan wejanganwejangan suci yang bersifat rahasia. Pada zaman upanisad seorang guru tidaklah mudah menerima muridnya dengan begitu saja, dan murid sangat kesulitan untuk menemukan seorang guru yang mau mengajarinya tentang pengetahuan suci. Namun seiring dengan berkembangnya zaman, pembelajaran pendidikan agama Hindu mengalami perkembangan yang sangat pesat ditandai dengan berdirinya asram, pasraman dan kemudian pendidikan agama Hindu dijadikan sebagai salah satu pelajaran yang wajib diikuti oleh peserta didik yang bergama Hindu. 
Dari pembelajaran upanisad pada zaman dahulu kemudian pembelajaran pendidikan agama Hindu perkembang ke sistem pembelajaran tradisonal. Pembelajaran tradisional adalah salah satu konsep lama dan hampir seluruh negara di dunia pernah menerapkannya. Pembelajaran tradisional adalah pembelajaran yang pada umumnya terpusat pada pendidik. Pada umumnya pembelajaran dengan sitem tradisional masih menggunakan metode mengajar yang sangat sederhana seperti menggunakan metode ceramah. Pembelajaran tradisional ini banyak digunakan oleh pendidik pada zaman dahulu. Penggunaan metode ceramah dalam pembelajaran membuat peserta didik menjadi bosan dan malas mengikuti pembelajaran, sehingga membuat proses pembelajaran berlangsung tidak optimal. Salah satu ciri dari sistem pembelajaran tradisional adalah bentemunya pendidik dan peserta didik secara langsung di dalam kelas. Pendidik dalam pembelajaran tradisional kebanyakan mengajar hanya sebatas memberikan informasi dan dinilai kurang membantu peserta didik. Dalam pembelajaran tradisional pendidik berperan sebagai sumber belajar. Menajemen pembelajaran dalam pembelajaran tradisional ditentukan oleh pendidik. Pembelajaran tradisional berorientasi pada pendidik bukan pada peserta didik. Media pembelajaran yang digunakan dalam pembelajaran tradisioal adalah pendidik itu sendiri. Pembelajaran yang berpusat pada pendidik merupakan sebuah tantangan, bagaimana pendidik memilih model pembelajaran yang tepat.

Pembelajaran menggunakan sistem tradisional sangat tidak tepat digunakan pada pendidikan agama Hindu saat ini karena dianggap kurang mengembangkan potensi yang dimiliki oleh peserta didik baik (dari segi kognitif, afektif dan psikomotorik) dan juga transfer materi dari pendidik ke peserta didik hanya sebatas ingatan sementara pada saat proses pembelajaran berlangsung. Kemudian dari sistem pendidikan tradisional, pembelajaran pendidikan agama Hindu beralih pada pembelajaran yang bersifat konvensional. Dalam pembelajaran dengan menggunakan metode konvensional ini pembelajaran tidak hanya terpusat kepada guru tetapi diimbangi dengan metode tanya jawab, diskusi dan ceramah yang membuat proses pembelajaran semakin interaktif. Namun pada penerapan metode konvensional ini tetap saja pembelajaran lebih banyak terpusat pada pendidik karena pendidik sebagai sumber informasi utama. Untuk dapat menciptakan pembelajaran pendidikan agama Hindu yang efektif saat ini, pembelajaran harus berpusat pada peserta didik (student center learning) dan juga penggunaan berbagai media digital dalam proses pembelajaran. Revitalisasi pembelajaran pendidikan agama Hindu di era disrupsi ditigal adalah sebagai berikut:

\section{a. Revitalisasi Sistem Pembelajaran}

Kurikulum pendidikan agama Hindu yang harus diterapkan pada era disrupsi ditigal adalah kurikulum berdiferensiasi sebagai pengembangan kompetensi kognitif, afektif dan psikomotorik peserta didik. Manusia dapat memperoleh wawasan dan pengetahuan baru dalam hidupnya melalui kegiatan belajar (Moh. Nawafil dan Junaidi 2020). Kurikulum berdiferensiasi merupakan suatu kurikulum yang dirancang untuk menumbuhkan potensi dan kreativitas yang menyangkut berbagai pengalaman belajar peserta didik. Kurikulum ini juga memperhatikan setiap perbedaan yang dimiliki oleh peserta didik baik dalam bidang akademik maupun non akademik. Dengan penerapan kurikulum ini diharapkan dapat menciptakan lingkungan pembelajaran yang holistik dan lebih menjunjung tinggi kesetaraan daripada kompetisi. Penerapan kurikulum berdiferensiasi tentu memerlukan seorang pendidik yang kompeten pada bidangnya, dan berkomitmen tinggi serta memiliki ruang gerak untuk terus berinovasi.

\section{b. Revitalisasi Pendidik dan Peserta Didik}

Selain dengan kurikulum berdiferensiasi revitalisasi pembelajaran pendidikan agama Hindu di era disrupsi digital dapat diwujudkan dengan pengembangan model dan pendekatan pembelajaran dengan memanfaatkan teknologi digital. Revitalisasi terhadap pemahaman yang dimiliki oleh seorang pendidik tentang kompetensi pedagogik dapat berimplikasi terhadap interaksi pedagogiknya dalam pembelajaran (Adi 2017). Kecakapan yang harus dimiliki oleh pendidik saat ini adalah kecakapan abad 21 yang meliputi learning and innovation skills, 
digital literacy dan life dan career skill. Sedangkan kecakapan abad 21 yang diperlukan oleh peserta didik untuk dapat meningkatkan daya saing di era disrupsi digital saat ini adalah pertama kualitas karakter peserta didik yang meliputi bagaimana peserta didik dapat beradaptasi dengan lingkungan yang dinamis. Kedua literasi digital yang meliputi bagaimana peserta didik dapat menerapkan ketermapilan dasar sehari-hari. Dan ketiga kemampuan menggunakan berbagai teknologi yang ada dan memiliki kompetensi yang meliputi bagaimana peserta didik memecahkan berbagai permasalahan dengan berpikir kritis, kreativitas, komunikasi dan kolaborasi.

\section{KESIMPULAN}

Pendidikan agama Hindu merupakan mata pelajaran yang wajib diterapkan di setiap sekolah yang terdapat siswa beragama Hindu. Peran penting pendidikan agama Hindu dalam membangun Sumber Daya Manusia Hindu yang unggul harus dapat diwujudkan. Di era disrupsi digital pembelajaran pendidikan agama Hindu dituntut untuk memanfaatkan teknologi digital yang ada saat ini. Pengembangan media pembelajaran interaktif berbasis digital sangat penting diterapkan dalam pembelajaran pendidikan agama Hindu di era disrupsi yang meliputi media pembelajaran interaktif berbasis e-Learning, software dan aplikasi android. Selain pengembangan media pembelajaran, pengembangan soft skill yang harus dimiliki seorang pendidik di era disrupsi digital juga sangat penting yang meliputi inovasi, kemampuan menggunakan teknologi digital, Collaboration dan Analytical Thungking dan Multi Tasking/ Paralel Tasking. Revitalisasi pemebelajaran pendidikan Agama Hindu di era disrupsi digital meliputi revitalisasi sistem pembelajaran yang meliputi penerapan kulikulum berdiferensiasi, model pembelajaran dan pegembangan media pembelajaran berbasis digital. Dan revitalisasi pendidik dan peserta yang meliputi kecakapan abad 21, pengembangan potensi diri dan pendidikan karakter.

\section{DAFTAR PUSTAKA}

Adi. 2017. "REVITALISASI INTERAKSI PEDAGOGIK GURU DENGAN SISWA DALAM PEMBELAJARAN." Tadrib: Jurnal Pendidikan Agama Islam 1 (2).

Anshori, Sodiq. 2016. "Strategi Pembelajaran Di Era Digital." Prosiding Temu Ilmiah Nasuinal Guru (Ting) VIII, no. November.

Arikunto, Suharsimi. 2019. "Dasar-Dasar Evaluasi Pendidikan." In Dasar-Dasar Evaluasi Pendidikan (Edisi 3).

Latifah Abdul Majid, Wan Nasyrudin Wan Abdullah, and Nurul Hidayah Ahmad Zakhi. 2012. "Penerapan Nilai Murni Dan Pembentukan Jati Diri Kanak-Kanak Prasekolah Melalui Penggunaan Multimedia.” Jurnal Hadhari Special Edition (2012) 51-65.

Moh. Nawafil, and Junaidi Junaidi. 2020. "Revitalisasi Paradigma Baru Dunia Pembelajaran Yang Membebaskan." Jurnal Pendidikan Islam Indonesia 4 (2). https://doi.org/10.35316/jpii.v4i2.193.

Nandi, Nandi. 2016. "PENGGUNAAN MULTIMEDIA INTERAKTIF DALAM PEMBELAJARAN GEOGRAFI DI PERSEKOLAHAN." Jurnal Geografi Gea. https://doi.org/10.17509/gea.v6i2.1741.

Pramudianto. 2020. Teacher As A Coach. Jakarta: PT Gramedia.

Putra, iIlham Eka. 2014. "Teknologi Media Pembelajaran Sejarah Melalui.” Jurnal Teknoilogi Informasi.

Sanaky, Hujair A. H. 2013. "Media Pembelajaran Interaktif-Inovatif." In Kaukaba Dipantara. Suwantana, I Gede. 2018. Tantangan Hindu Di Indonesia. Denpasar: PT Japa Widya Duta. Syamsuar, and Reflianto. 2018. "Pendidikan Dan Tantangan Pembelajaran Berbasis Teknologi Informasi Di Era Revolusi Industri 4.0.” Pendidikan Dan Tantangan 
Pembelajaran Berbasis Teknologi Informasi Di Era Revolusi Industri 4.0. https://doi.org/https://doi.org/10.24036/et.v2i2.101343. 